\title{
Triquilemoma Desmoplástico em Nevo Sebáceo do Couro Cabeludo
}

\author{
Rui Tavares-Bello', Óscar Tellechea², Sónia Fernandes ${ }^{3}$ \\ 'Dermatology Service, Hospital Militar de Belém, Lisboa. Presently, Hospital dos Lusíadas, Lisboa, Portugal \\ 2Dermatology Service, Hospitais da Universidade de Coimbra, Portugal \\ ${ }^{3}$ Dermatology Service, Hospital de Curry Cabral, Lisboa. Presently, Hospital dos Lusíadas and Hospital de Santa Maria-CHLN, Lisboa, \\ Portugal
}

\begin{abstract}
RESUMO - Descrito originalmente por Jadassohn em 1895, foi apenas em 1932 que a designação "nevo sebáceo" foi introduzida, por Robinson. Trata-se de um hamartoma congénito relativamente prevalente que, classicamente, evolui por fases de crescimento e maturação (classicamente estão descritas 3 fases: infância <12; adolescência 12-18; adultos >18) e que, do $4^{\circ}$ ao $7^{\circ}$ decénios pode originar, em 10-30\% dos casos), várias neoplasias epiteliais. Muito raramente reportados neste contexto, os triquilemomas são tumores anexiais benignos que se originam ou diferenciam no epitélio da bainha radicular externa folicular. Habitualmente solitários, podem apresentar-se clinicamente como pápulas translúcidas ou queratósicas faciais, em particular na proximidade da pirâmide nasal e dos lábios. A rara variante histológica "triquilemoma desmoplásico" pode simular clinicamente basaliomas (CBC), carcinomas espinhocelulares (CEC), nevos intradérmicos, verrugas virais, cornos cutâneos ou hiperplasias sebáceas e, histologicamente, evocar variantes desmoplásicas de CBCs, CECs e de carcinomas triquilémicos. É apresentado caso de doente eurocaucasiano de 56 anos de idade que apresentava pápulas e nódulos translúcidos assintomáticos, desenvolvidos num nevo sebáceo do couro cabeludo. O estudo histológico revelou uma proliferação lobular com as características clássicas do triquilemoma desmoplásico no seio de um hamartoma sebáceo. O caso é ilustrado iconograficamente e a literatura relevante é sumariamente revista.
\end{abstract}

PALAVRAS-CHAVE - Nevo; Neoplasias das Glândulas Sebáceas; Neoplasias da Pele.

\section{Desmoplastic Trichilemmoma arising on a Nevus Sebaceous of the Scalp}

ABSTRACT - Originally described by Jadassohn in 1895, it was not until 1932 that the term "nevus sebaceous" was introduced by Robinson. It is a prevalent benign congenital hamartoma that classically evolves through discrete phases of growth and that, from the 4th to the 7th decade of life, can give rise in approximately 10 to $30 \%$ of cases to several epithelial neoplasms. Very seldom reported in this context, trichilemmomas are benign appendageal tumours that arise from or differentiate toward the outer root sheath epithelium of the normal hair follicle. Usually solitary, they present as verrucous, keratotic or smooth papules on the face, especially in the vicinity of the nose and lips. On clinical grounds, desmoplastic trichilemmomas, a rare benign histological sub-type of trichilemmomas, are easily taken for basal cell carcinomas, intradermal nevi, verrucae, cutaneous horns, sebaceous hyperplasia and squamous cell carcinomas; as far as pathology, differential diagnosis must include the desmoplastic variants of squamous and basal cell carcinomas, as well as trichilemmal carcinoma. A 56 year old Caucasian male presented with several asymptomatic pearly, translucid nodules and papules that had developed over the last 6 months within a congenital alopecic yellowish plaque of his scalp previously diagnosed, on clinical grounds, as a nevus sebaceous. Histopathological examination allowed to disclose a lobular neoplasm with the classic features of desmoplastic trichilemmoma. The case is iconographically depicted and the relevant literature is reviewed.

KEY-WORDS - Nevus; Sebaceous Gland Neoplasms; Skin Neoplasms.

Correspondência: Rui Tavares-Bello

Consulta de Dermatologia - Hospital dos Lusíadas

Rua Abílio Mendes - 1500-458 Lisboa, Portugal
Recebido/Received

10 Fevereiro/10 February 2016

Aceite/Accepted

20 Março/20 March 2016 


\section{Caso Clínico}

\section{INTRODUCTION}

Described by Headington and French in $1962^{1}$ trichilemmomas $(\mathrm{Tr})$ are benign tumours differentiating toward to the hair follicle isthmus. In 1990, Hunt at al ${ }^{2}$ described a desmoplastic histological variant characterized by a pseudocarcinomatous silhovette that often led to the misdiagnosis of desmoplastic squamous cell carcinoma or basal cell carcinoma.which evoked an invasive desmoplastic squamous cell carcinoma. Clinically, trichilemmomas may present either as solitary nondescript verrucous small papules at the central part of the face or, rarely, as multiple lesions at the same location, a circumstance where - together with sclerotic fibromas and acrokeratosis verruciformis - the diagnosis of Cowden's syndrome should be evoked. Trichilemmomas may also, although rarely, occur as a secondary neoplasm within the milieu of a nevus sebaceous $(N S)^{3}$ the very similar way varied appendageal tumours do, in what is regarded by some as a third stage in the natural history of NS. ${ }^{4,5}$. Pathologically, desmoplastic trichilemmoma (DTr) consists of well-defined lobules extending from the epidermis into the dermis centered by a dense, abundant hyaline stroma. In most cases, the epithelial lobules show at their margins the typical features of Tr lobules, with polygonal, PAS + clear cells exhibiting peripheral nuclear palisading that lie upon a thickened eosinophilic hyaline membrane. As the center of the lesion is approached, the epithelial sheaths progressively get narrower, cells diminishing in dimension and becoming more and more irregular. When cells merge on the dense stroma, the lobular pattern is disrupted and cells tend to cluster in irregular cords or nests, with occasional dyskeratosis or necrosis, thus simulating an invasive carcinoma. ${ }^{2,3,6}$ The case of a 56 year old Caucasian male who developed a desmoplastic trichilemmoma within a nevus sebaceous of the scalp is presented.

\section{CASE REPORT}

A 56 year old Caucasian male presented with several asymptomatic papules that had developed over the last 6 months within an alopecic plaque on the scalp, previously diagnosed, on clinical grounds, as a sebaceous nevus. He denied any previous local major trauma, radiation therapy or topical agents as well as any family or personal history of skin or visceral cancer. He had lived his whole life in Angola but, due to his fair complexion, had always avoided deliberate or any kind of recreational sun exposure.

On physical examination, the patient had several papules - from 3 to $6 \mathrm{~mm}$ diameter - superimposed, in an apparently multifocal distribution, on a 15X12 mm diameter, alopecic, slightly raised yellowish plaque with a smooth, velvety surface (Fig. 1). The papules were hemispheric or pedunculated, some warty and some translucid. The examination of the rest of the integument was nondescript.

The patient declined to undergo excision of the entire mass. A biopsy was then suggested for diagnostic purposes, which was readily accepted. A large shave biopsy that involved the whole lesion was then performed, with subsequent $\mathrm{CO} 2$ laser vaporization of the resulting open wound, for the sake of hemostasis.

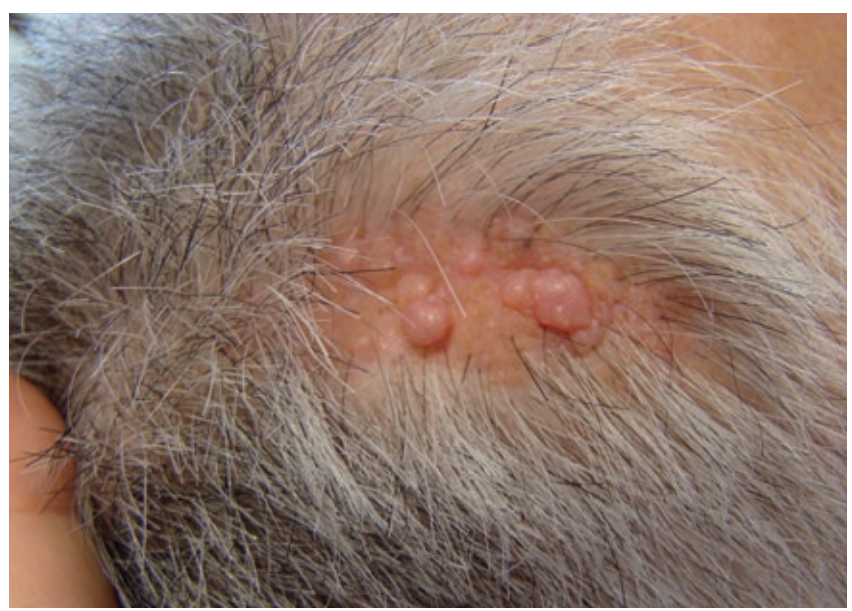

Figure 1 - Several papules on a 15x12 mm alopecic, yellowish plaque with a smooth surface on the scalp.

Histological examination revealed an endoexophytic epithelial proliferation that filled the dermis and was contiguous to the overlying acanthotic epidermis (Fig. 2). The neoplasm was composed of well-demarcated lobules, with two populations of epithelial cells: one, centrally located, with clear and abundant cytoplasm (Fig. 3) and the other, peripherally, with basophilic cells with nuclear palisading lined by a thickened eosinophilic hyaline membrane (Fig. 4). Overall, a dense hypercellular

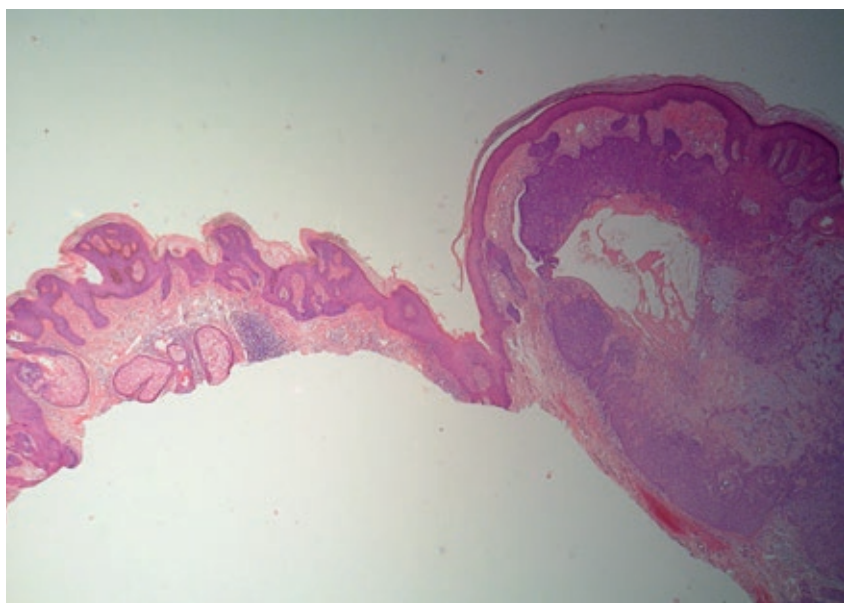

Figure 2 - A well-defined lobular proliferation, connected to epidermis.

and desmoplastic stroma occupied the central portion of the proliferation (Fig. 5). There was neither evidence of cytological atypia nor of mitotic figures. At the extreme periphery of the histological section, one could appreciate some trabecular acanthosis of the epidermis, hyperplastic sebaceous glands some opening directly to the surface - and a focal lymphomononuclear inflammatory infiltrate (Fig. 6).

The diagnosis of desmoplastic trichilemmoma arising in a sebaceous nevus was made. The tumour appeared to be fully confined within the limits of the tissue specimen, suggesting 


\section{Caso Clínico}

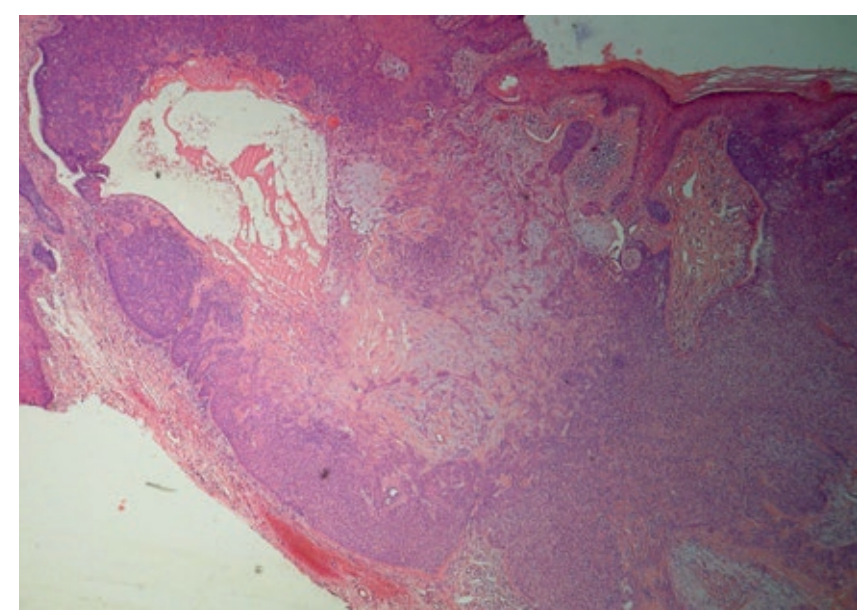

Figure 3 - Overview of the epithelial tumour with 2 distinct cell populations.

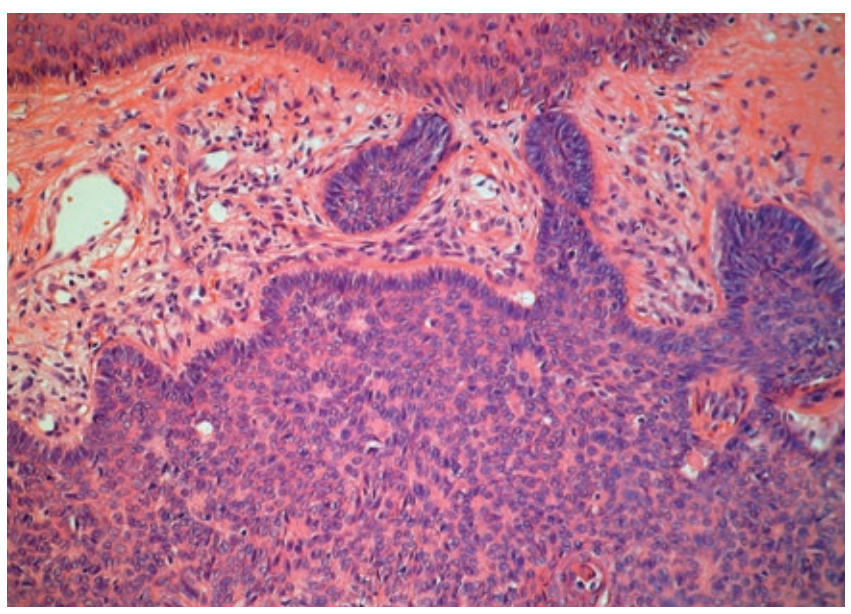

Figure 4 - Peripherally-located cellular aggregates with basophilic cells with nuclear pallisading and thickened basement membrane.

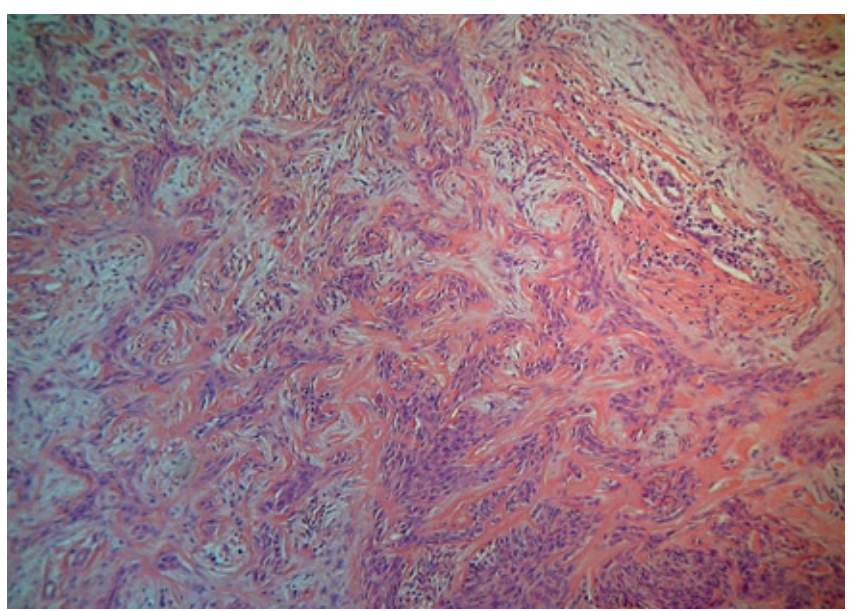

Figure 5 - Detail of the hypercellular desmoplastic stroma.

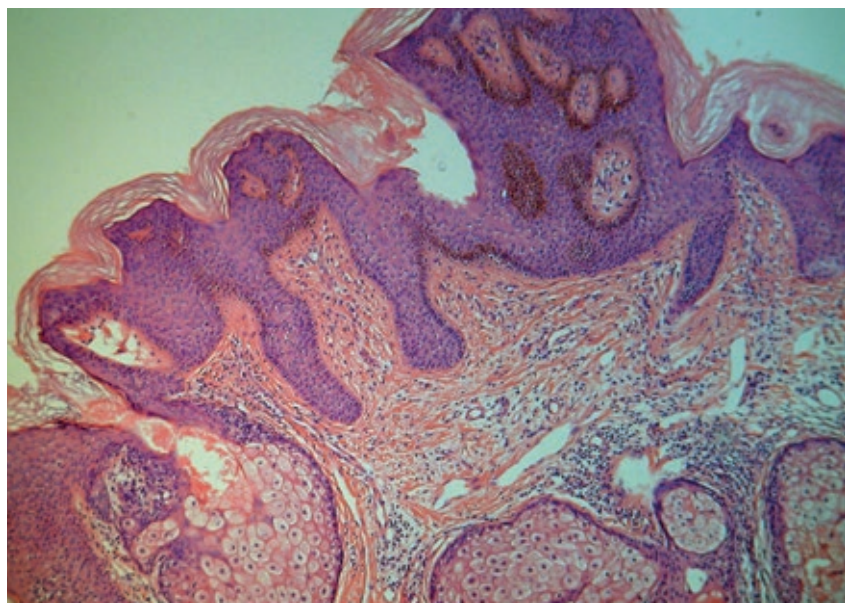

Figure 6 - Periphery of the lesion nevus sebaceous detail.

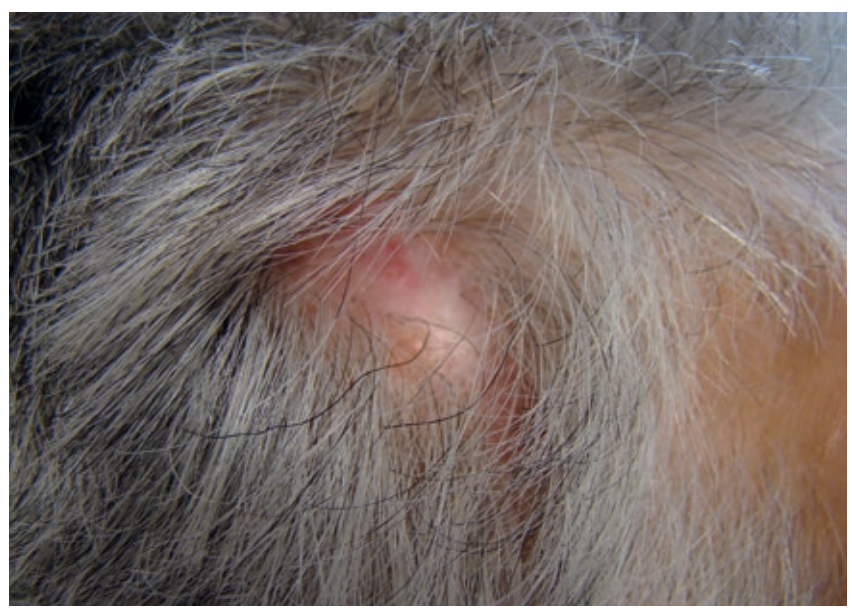

Figure $\mathbf{7}$ - At follow-up, there was no recurrence of the neoplasm.

that a complete excision had been performed. Meanwhile, the resulting surgical wound, which measured $10 \times 6 \mathrm{~mm}$ diameter, fully healed by second intention, in a three-week period without major pain or complications. At follow-up, 12 months afterwards, there was no recurrence of the neoplasm (Fig. 7). Although fully informed about the possible development of other local neoplasms, the patient nevertheless refused to undergo complete excision of the congenital sebaceous nevus.

\section{DISCUSSION}

Originally described by Jadassohn in 1895, it was not until 1932 that the term "nevus sebaceous of Jadassohn" (NS) was introduced, by. ${ }^{7}$ It refers to a well-recognized congenital hamartoma of the skin that appears as a slightly raised, yellowish, smooth alopecic plaque on the scalp, face and neck. It evolves through distinct phases of growth, clearly accelerated at puberty, when it may show a hyperplastic, nodular appearance and, at adulthood ( $4^{\text {th }}-7^{\text {th }}$ decades), where can give rise, 
in approximately $10-30 \%$ of cases, to diverse epithelial neoplasms. ${ }^{8,9}$ Several reported activating mutations in HRAS and KRAS have been reported in nevus sebaceous, so as to allow to be envisioned by some authors it as the result of a proliferative whole skin somatic mosaic status. ${ }^{10-12}$ Most of these tumours are benign and have a pilar, sebaceous, eccrine or apocrine origin. Malignant neoplasms are extremely rare among children as well as in adults, as it has been shown that most of the lesions formerly classified in this setting as basal cell carcinomas (BCC) were actually trichoblastomas. ${ }^{5,13}$

Since its original description in $1990,{ }^{2}$ desmoplastic trichilemmomas (DTr) have very seldom been reported, particularly in the setting of NS., ${ }^{2,14}$ DTr?'s are indeed very infrequent tumours. ${ }^{6,15}$ The total of only 81 cases reported worldwide up to 2012 may in fact represent an underestimation of the actual prevalence of these tumours. It has been reported to occur in several ethnicities, seeming to be more prevalent in males and to favor the $5^{\text {th }}-6^{\text {th }}$ decades of life. As far as location, DT's seem to predominate on the facial area, although extrafacial locations have also been described. ${ }^{15}$ Clinically, its presentation is quite non-specific, either as a lobular or diffuse thickening of a previous NS or as newly superimposed translucid or keratotic papules and nodules. In fact, desmoplastic trichilemmomas in this context can be easily taken for viral warts, intradermal nevi, seborrheic keratoses, BCC, SCC or cutaneous horns, ${ }^{2,3}$ as such requiring histological examination in each and every case.

Histologically, desmoplastic trichilemmomas present as well defined lobular lesions in the upper dermis with typical features of trichilemmoma at the periphery, but with a desmoplastic stroma at the very center of the growth. The stroma characteristically "dissecates" the nearby lobules originating irregular cords and nests of basaloid cells admixed in the dense, hyaline connective tissue. The amount of desmoplasia is said to vary, but in most cases represents about $20-60 \%$ of the tumour. ${ }^{2,6}$ It is important not to misdiagnose this pseudoinvasive pattern as an invasive carcinoma. Although some cytological pleomorphism, individual dyskeratosis and cellular necrosis may focally be present, overall, the absence of frank cell atypia and mitotic activity do favor a diagnosis of DTr. In difficult cases however, the CD 34 positive and BerEP4 negative immunostaining of the epithelial cells allow to definitely clarify diagnosis and rule out BCC. ${ }^{16}$

In our patient's case, as opposed to the non-specific clinical presentation, the pathological examination allowed to clearly diagnose DTr within a nevus sebaceous.

As far as therapeutic intervention in NS, a lot of controversy does exist in the literature. Prophylactic surgery during childhood has classically been advocated at the light of the natural history of NS and the early assumed risk of malignancy, namely basal cell carcinoma, as the lesion ages. ${ }^{12-14,17-19}$ As opposed to that view, others have suggested that prophylactic surgery should not systematically be performed due to the more modern evidence of its low malignancy risk. ${ }^{5}$ In the context of these pros and cons however, we do believe that the decision should be the result of a careful individual based, case-by-case consideration, whereby several facts should be weighed: 1. Secondary neoplasms (mostly benign) are a common occurrence in NS's: 2. On clinical grounds, changes in long lasting NS's of the scalp are hardly if ever noticeable; 3 . Secondary neoplasms often lack clinical specific features as to allow to clinically differentiate between benign or malignant; 4 . Some molecular evidence does exist in that NSs share with BCCs a defect of the tumour suppressor gene PTCH (9q22.3), which might be in keeping with a definite carcinogenic potential of NS (20). Thus, having these data in mind, we suggest that at least in most of the NS's of the scalp area, surgical excision is indeed advisable. That was not unfortunately our patient's case, in whom due to personal schedule limitations, we were only able to perform a large (excisional) biopsy of the desmoplastic trichilemmoma, without being able to completely remove the nevus sebaceous.

In what concerns DT treatment, although usually benign, its potential coexistence with atypical basaloid cell proliferations including $\mathrm{CBC}$, makes Mohs surgery (for both adequate margin control and tissue sparing benefits) $)^{15,21}$ or complete surgical excision with pathological confirmation of clear margins the treatments of choice. ${ }^{22}$

In summary, a case of a patient with a desmoplastic trichilemmoma arising in a nevus sebaceous of the scalp is reported. Diagnostic and therapeutic challenges posed by this rare tumour when in the context of a complex, still enigmatic skin hamartoma such as nevus sebaceous are discussed.

Conflitos de interesse: Os autores declaram não possuir conflitos de interesse. Suporte financeiro: $O$ presente trabalho não foi suportado por nenhum subsídio ou bolsa. Direito à privacidade e consentimento escrito: Os autores declaram que pediram consentimento ao doente para usar as imagens no artigo.

Conflicts of interest: The authors have no conflicts of interest to declare. Financing Support: This work has not received any contribution, grant or scholarship. Privacy policy and informed consent: The authors declare that the patient gave written informed consent for the use of its photos in this article.

\section{REFERENCES}

1. Headington JT, French AJ. Primary neoplasms of the hair follicle: histogenesis and classification. Arch Dermatol. 1962;86:430-41.

2. Hunt SJ, Kilzer B, Santa Cruz DJ. Desmoplastic trichilemmoma: histologic variant resembling invasive carcinoma. J Cutan Pathol. 1990;17:45-52.

3. Rosõn E, Gomez Centeno P, Sanchez-Aguilar D. Desmoplastic trichilemmoma arising within a nevus sebaceous. Am J Dermatopathol. 1998; 20: 495-7.

4. Mehregan AH, Pinkus $H$. Life history of organoid nevi. Arch Dermatol. 1965; 91:574-88.

5. Cribier B, Scrivener Y, Grosshans E. Tumors arising in nevus sebaceous: A study of 596 cases. J Am Acad Dermatol. 2000; 42:263-8. 


\section{Caso Clínico}

6. TellecheaO, Reis JP, Poiares Baptista A. Desmoplastic trichilemmoma. Am J Dermatopathol. 1992; 14: 107-14.

7. Robinson SS. Nevus Sebaceous (Jadassohn): report of five cases. Arch Dermatol Syphilol.1932; 26:663-70.

8. Shapiro M, Johnson B Jr, Witmer W, Elenitsas R. Spiradenoma arising in a nevus sebaceous of Jadassohn: case report and literature review. Am J Dermatopathol.1999; 21:462-7.

9. Idriss $M H$, Elston DM. Secondary neoplasms associated with nevus sebaceous of Jadassohn: a study of 707 cases. J Am Acad Dermatol. 2014;70:332-7.

10. Groesser L, Herschberger E, Ruetten A, Ruivenkamp C, Lopriore E, Zutt M, et al. Postzygotic HRAS and KRAS mutations can cause nevus sebaceous and Schimmelpenning syndrome. Nat Genet. 2012; 44:783-7.

11. Aslam A, Salam A, Griffiths CE, McGrath JA. Nevus sebaceous: a mosaic RA Sopathy. Clin Exp Dermatol. 2014; 39:1-6.

12. Happle R. Nevus sebaceous is a mosaic RA Sopathy. J Invest Dermatol.2013; 133:597-600.

13. Jacqueti G, Requena L, Sanchez Yus E. Trichoblastoma is the most common neoplasm developed in nevus sebaceous of Jadassohn: a clinicopathologic study of a series of 155 cases. Am J Dermatopathol. 2000; 22:108-18.

14. Crowson AN, Magro CM. Basal cell carcinoma arising in association with desmoplastic trichilemmoma. Am J Dermatopathol.1996; 18:43-8.
15. Afshar M, Lee RA, Jiang SI. Desmoplastic Trichelemmoma - A Report of Successful Treatment with Mohs Micrographic Surgery and a Review and Update of the Literature. Dermatol Surg. 2012; 38: 1867-71.

16. Illueca C, Monteagudo C, Revert A, Llombart-Bosch A. Diagnostic value of CD34 immunostaining in desmoplastic trichilemmoma. J Cutan Pathol. 1988; 25:435-9.

17. Fergin PE, Chu AC, MacDonald DM. Basal cell carcinoma complicating nevus sebaceous. Clin Exp Dermatol. $1981 ; 6: 111-5$.

18. Jones EW, Heyl T. Nevus sebaceous: a report of 140 cases with special regards to the development of secondary malignant tumors. Br J Dermatol. 1970; 82:99117.

19. Domingo J, Helwig EB. Malignant neoplasm associated with nevus sebaceous of Jadassohn. J Am Acad Dermatol. 1979; 1:545-56.

20. Xin H, Matt D, Qin JZ, Burg G, Böni R. The Sebaceous Nevus: A Nevus with Deletions of the PTCH Gene. Cancer Res. 1999; 59: 1834-6.

21. Schweiger E, Spann CT, Weinberg JM, Ross B. A Case of Desmoplastic Trichilemmoma of the Lip Treated with Mohs Surgery. Dermatol Surg. 2004; 30:1062-4.

22. Sano DT, Yang JJ, Tebcherani AJ, Bazzo LA. A rare clinical presentation of Desmoplastic Trichilemmoma mimicking Invasive Carcinoma. An Bras Dermatol. 2014; 89:796-8. 